\title{
Food Allergy in Youth: A Primer for Allied Health Professionals
}

Philip Welch

Bowling Green State University - Main Campus, pjwelch@bgsu.edu

Lauren Maziarz

Bowling Green State University, Imaziar@bgsu.edu

Macy McCartney

Bowling Green State University, macym@bgsu.edu

Chelsea Raker

Bowling Green State University, rakerc@bgsu.edu

Follow this and additional works at: https://nsuworks.nova.edu/ijahsp

Part of the Health and Physical Education Commons, Immune System Diseases Commons, and the Maternal and Child Health Commons

\section{Recommended Citation}

Welch P, Maziarz L, McCartney M, Raker C. Food Allergy in Youth: A Primer for Allied Health Professionals. The Internet Journal of Allied Health Sciences and Practice. 2018 Jan 01;16(4), Article 7.

This Review Article is brought to you for free and open access by the College of Health Care Sciences at NSUWorks. It has been accepted for inclusion in Internet Journal of Allied Health Sciences and Practice by an authorized editor of NSUWorks. For more information, please contact nsuworks@nova.edu. 


\title{
Food Allergy in Youth: A Primer for Allied Health Professionals
}

\begin{abstract}
Purpose: Many youth struggle with the physical, mental, and social burdens of food allergy. The exact cause of food allergies is unknown, but several theories exist such as the "couch potato theory", "hygiene hypothesis", "microflora theory", and "alarmins" theory. This non-systematic literature review summarizes the problem of youth food allergy and provides guidance to allied health professionals.

Method: A literature search of the relevant literature from years 2000 through 2017 was conducted using PubMed with the key words "food allergy", "youth", and "management".

Results: Youth with food allergy may experience anxiety, social isolation, bullying, and depression, in addition to life-threatening allergic reactions. Managing food allergies successfully requires a team approach and begins with accurate diagnosis and identification/avoidance of specific food protein triggers.

Conclusions: Several federal laws exist to help protect food allergic youth from accidental exposure. Allied health professionals play important roles in helping adolescents avoid life-threatening reactions to food allergens.
\end{abstract}

\section{Author Bio(s)}

Philip J. Welch, PhD, MCHES, Assistant Professor of Public \& Allied Health and Graduate Coordinator in the College of Health \& Human Services at Bowling Green State University in Bowling Green, $\mathrm{OH}$. $\mathrm{He}$ is also a Master Certified Health Education Specialist.

Lauren Maziarz, PhD, RN, Assistant Professor of Public \& Allied Health in the College of Health \& Human Services at Bowling Green State University in Bowling Green, $\mathrm{OH}$.

Macy McCartney, Graduate Assistant in the College of Health \& Human Services at Bowling Green State University in Bowling Green, $\mathrm{OH}$.

Chelsea Raker, Graduate Assistant in the College of Health \& Human Services at Bowling Green State University in Bowling Green, $\mathrm{OH}$. 


\section{InternetJournal ofAlliedHealthSciences and Practice}

\section{Food Allergy in Youth: A Primer for Allied Health Professionals: ALiterature Review}

Philip Welch

Lauren Maziarz

Macy McCartney

Chelsea Raker

Follow this and additional works at: https://nsuworks.nova.edu/ijahsp

Part of the Health and Physical Education Commons, Immune System Diseases Commons, and the Maternal and Child Health Commons 


\section{Food Allergy in Youth: A Primer for Allied Health Professionals: A Literature Review}

Purpose:Manyyouthsstrugglewiththephysical, mental, and socialburdens offoodallergy. Theexactcause of food allergies is unknown, but several theories exist, such as the "couch potato theory," "hygiene hypothesis," "microflora theory," and "false alarm" theory. With this non-systematic literature review, we have summarized the problem of youth food allergy and provided guidance to allied health professionals.

Method: A literature search of the relevant literature from years 2000 through 2017 was conducted using PubMed with the key words "food allergy," "youth," and "management."

Results: Youth with afood allergy may experience anxiety, social isolation, bullying, and depression in addition to life-threatening allergic reactions. Managing food allergies successfully requires a team approach and begins with accurate diagnosis and identification/avoidance of specific food protein triggers.

Conclusions: Several federal laws exist to help protect food allergic youth from accidental exposure. Allied health professionals play important roles in helping adolescents avoid life-threatening reactions to food allergens. 


\title{
1IVAHSP \\ The Internet Journal of Allied Health Sciences and Practice \\ Dedicated to allied health professional practice and education \\ Vol. 16 No. 4 ISSN 1540-580X
}

\section{Food Allergy in Youth: A Primer for Allied Health Professionals: A Literature Review}

\author{
Philip J. Welch, PhD, MCHES \\ Lauren Maziarz, PhD, RN \\ Macy McCartney, Grad. Assist. \\ Chelsea Raker, Grad. Assist. \\ Bowling Green State University \\ United States
}

\begin{abstract}
Purpose: Many youths struggle with the physical, mental, and social burdens of food allergy. The exact cause of food allergies is unknown, but several theories exist, such as the "couch potato theory," "hygiene hypothesis," "microflora theory," and "false alarm" theory. With this non-systematic literature review, we have summarized the problem of youth food allergy and provided guidance to allied health professionals. Method: A literature search of the relevant literature from years 2000 through 2017 was conducted using PubMed with the key words "food allergy," "youth," and "management." Results: Youth with food allergy may experience anxiety, social isolation, bullying, and depression in addition to life-threatening allergic reactions. Managing food allergies successfully requires a team approach and begins with accurate diagnosis and identification/avoidance of specific food protein triggers. Conclusions: Several federal laws exist to help protect food allergic youth from accidental exposure. Allied health professionals play important roles in helping adolescents avoid life-threatening reactions to food allergens.
\end{abstract}

Keywords: Food allergy, youth, management, allied health professionals

\section{INTRODUCTION}

Food allergy affects an estimated $4 \%$ to $12 \%$ of youths in developed countries with the prevalence of all types of food allergies increasing. ${ }^{1-6}$ The Centers for Disease Control and Prevention reported a $50 \%$ increase in food allergy among children between 1997 and 2011. ${ }^{7}$ Difficulty exists in determining prevalence of food allergy via self-report due to the potential presence of similar, confounding gastrointestinal conditions like food intolerance. For example, a person thought to be allergic to milk protein may simply be lactose intolerant. ${ }^{8}$ Some researchers estimate that up to $20 \%$ of people eat an altered diet because of perceived adverse allergic reactions to food when in fact they are experiencing a non-allergic response to the food. ${ }^{9}$

The foods that most commonly trigger allergic reactions are milk, eggs, peanuts, tree nuts, wheat, soy, fish, and shellfish. ${ }^{10}$ Some youths might outgrow their hypersensitivity to food proteins during adolescence, depending upon the type of food allergy (egg, milk, nut, etc.), individual symptom severity, specific lgE antibody levels, age at diagnosis, and presence or absence of multiple allergies. ${ }^{11}$ It is estimated that among the $1 \%$ to $2 \%$ of children afflicted with egg allergy, $4 \%$ will outgrow their egg allergy by age $4,12 \%$ by age $6,37 \%$ by age 10 , and $68 \%$ by age $16 .{ }^{12}$ Approximately $70 \%$ of children will outgrow egg allergy by age 16 years 
and most youth tolerate well-cooked eggs sooner than uncooked eggs. ${ }^{13}$ However, those whose egg allergy persists are more likely to have a severe allergy as well as endure additional food allergies and atopy in general. ${ }^{13}$ Some $50 \%$ of children will outgrow their allergy to cow's milk by age $1^{14}$ while peanuts are a more persistent allergen. There is some evidence to suggest that infants can occasionally outgrow their hypersensitivity to peanut ${ }^{15,16}$ and that up to $20 \%$ of young children eventually outgrow this allergy ${ }^{17}$ The eventual resolution of allergy to fish is rare. ${ }^{18}$

\section{BACKGROUND}

\section{Causes of Food Allergy}

Risk factors for food allergy include a family history of asthma and allergies, genetic predisposition to other types of allergic disease, elevated allergen-specific serum immunoglobulin levels (IgE concentrations), and being younger than 3 years old. 19,20 However, the cause of food allergy is unknown. There are numerous theories that attempt to explain food allergy etiology, such as the "hygiene hypothesis" proposed by D.P. Strachan in 1989. Dr. Strachan found that younger siblings in large families have fewer allergy problems than do their older siblings. ${ }^{21} \mathrm{Dr}$. Strachan hypothesized that the younger children experience more infections brought home by their older siblings, thus protecting the young siblings against many forms of allergic disease later in life. Research from Austria, Canada, Germany, and Finland lend credence to the hygiene hypothesis via evidence that farm-reared children have fewer allergic diseases perhaps because of increased exposure to airborne and soil-borne bacteria, molds, and animal dander. ${ }^{3}$ In particular, parasitic infestations are associated with a decreased risk of developing allergies.22

In a related environmental-based theory, Polosa et al posit that city-dwelling and the associated exposure to air pollutants from industry and automobile exhaust may alter the body's normal immune functioning. ${ }^{23}$ With this theory, the high rates of asthma in inner city children may be partially explained as well as the observation that persons living in large metropolitan statistical areas (populations over $1,000,000$ ) are 3 times as likely to have any kind of food or digestive allergy compared with rural counterparts. ${ }^{24}$ In a different theory, in which Dr. Thomas Platts-Mills called the couch potato theory, he suggested that the sedentary lifestyles of today's youth in addition to contributing to the childhood obesity epidemic are also keeping children indoors too long, which exposes them to the many indoor allergens present in poorly ventilated homes. ${ }^{3}$ The couch potato theory may be used to explain the association between obesity and the rise in asthma and respiratory disorders in clean air climates, ${ }^{24}$ but it does little to acknowledge the rise in food allergies in infants. To explain the rise in infant allergy, some scientists posit that birth by cesarean section fails to expose the newborn to essential microbials in the birth canal. Lack of microbial exposure during birth may lead to abnormal immune system development. ${ }^{25}$

The microflora hypothesis is a more recent theory in which Skypala and Vlieg-Boerstra speculated that the allergy epidemic is due to the overuse of antibiotics, which kill friendly bacteria in the intestinal tract. They also proposed that a westernized diet is partially to blame for food allergies due to a lack of fruits, vegetables, unsaturated fatty acids, and unpasteurized milk. ${ }^{26}$ This theory is supported by evidence that the industrial processing of food that is characteristic of western diets destroys the structure of food proteins necessary for normal immunologic functioning. ${ }^{11}$ In a related theory, Ekmay et al. suggested that overuse of antacid medications increases gastric $\mathrm{pH}$ that then impairs the ability of pepsin to digest allergenic proteins. Researchers are claiming this reason could be part of the rise of incidence of food allergies. ${ }^{27}$ Alternatively, maternal eating habits may guard against food allergy. Peanut and egg protein have been found to pass through breast milk, potentially affecting the infant's immunologic response to those proteins. ${ }^{28}$ Finally, with the "false alarm" theory, Smith suggested that the biochemical agents known as "alarmins" are the real culprits with food allergy and are enhanced by the western lifestyle and diet. According to the researchers, alarmins are "endogenous molecules secreted from cells undergoing programmed cell death that signal tissue and cell damage. The western lifestyle and diet may be the trigger for alarmins." One of the major alarmins is high molecular group S (HMGB1) that binds to the receptor for advanced glycation products (AGE). This hypothesis presents that the western diet is rich in advanced glycation end products. The bodies' misinterpretation of AGEs could cause food allergies. ${ }^{29}$

\section{Diagnosing Food Allergy}

Understanding how food allergy is diagnosed can help allied health professionals effectively communicate with food allergic clients. A pediatrician or allergy specialist typically makes the initial diagnosis of food allergy. A primary care provider should make the definitive diagnosis and treatment plan. ${ }^{30}$ Newer, more sensitive light-based assays have replaced older Radioallergosorbent Tests (RAST) and are used to determine allergen-specific immunoglobin E levels (slgE). Skin prick tests are also commonly used to aid in diagnosing food allergy. ${ }^{31}$ The slgE requires blood sampling and analysis at a medical laboratory to determine whether the patient has IgE antibodies to particular food proteins. A skin prick test is less expensive and begins in the doctor's office by pricking the skin of the patient and applying a drop of a specific food allergen, such as peanut, directly to the prick site. A positive prick test, which is a wheal that is $3 \mathrm{~mm}$ greater than the control, indicates "sensitization" to the allergen but does not diagnose a food allergy. To diagnose a food allergy there must be both a compatible history of a food allergic reaction and a positive prick test. A negative prick test, however, essentially excludes a food allergy being present. ${ }^{32}$ 
Many doctors use a slgE for young children with eczema or other skin conditions that would make reading a skin prick test difficult. The results of the skin prick test or slgE test should be combined with symptom history to determine if a food allergy truly exists. ${ }^{32}$ The definitive, gold standard test is the double-blind placebo-controlled food challenge (DBPCFC) in which the food-allergic child ingests a small quantity of the offending protein and is monitored by medical personnel for a reaction. The DBPCFC must only be done in a hospital setting or an appropriately staffed and equipped allergist office under close medical supervision in the event of an adverse reaction. Diagnostic tests exist that should never be used for the diagnosis of food (or inhalant) allergy. Examples include hair analysis, cytotoxic test, electrodermal test (VEGA), applied kinesiology, iridology, provocation-neutralization, and the pulse test. These methods have no scientific evidence to support their efficacy. ${ }^{33}$

\section{Disease Burden}

Food allergy severity and disease burden varies by individual. The range of burden extends from minor annoyance to severe physical, social, and psychological disability. A food allergic individual who ingests the offending allergen will typically show signs and symptoms within a few minutes to 2 hours. ${ }^{34}$ Allergic reactions vary by individual and can include hives; rash; itchiness; coughing or wheezing; dizziness; difficulty breathing; abdominal cramps; vomiting; diarrhea; or swelling of the throat, tongue, face, and lips. The initial, mild symptoms (hives, rash, and itchiness) are not always an indication that the reaction will be mild and not life-threatening. If not treated quickly, these symptoms can rapidly lead to anaphylaxis, the most severe, life-threatening allergic reactions to food. Anaphylaxis can cause constricting of the lungs, lowering of blood pressure, shock, and suffocation due to swelling of the throat. In the United States, every 3 minutes, an allergic reaction to food sends someone to the emergency department. Every year, over 200,000 people require emergency medical care for severe allergic reactions to food ${ }^{35}$ Risk factors associated with fatal or near-fatal anaphylaxis include a history of food allergy, especially if severe; allergy to peanuts or tree nuts; asthma (even mild asthma); younger age; and delay in appropriate treatment. ${ }^{5}$

Being burdened by a food allergy in youth can mean having to adhere to a strict diet, experience possible growth failure, use medications, and can potentially lead to hospital admission. Dietary manipulation and restriction without supervision from a qualified dietitian may lead to additional health problems. ${ }^{36}$ Adolescents with 2 or more food allergies can be shorter in stature and ingest less calcium and other minerals and vitamins when compared with youth with only 1 allergy or age-matched controls. ${ }^{37}$ Medial providers must assure that food-allergic youth, especially those with multiple food allergies, have a diet that includes adequate calcium, minerals, vitamins, and protein. Individuals with food allergy tend to experience daily manifestations of their disease. Difficulty with adhering to a strict diet can lead to social isolation and depression. While not recommended, food-allergic youth are often physically separated from friends during school lunch periods, such as placed at "nut-free" tables. Social gatherings, such as school dances or birthday parties, can be risky events for the food allergic. The fear of eating food contaminated with an allergen may limit youth from fully engaging in social events, which exacerbates feelings of isolation. In a study of 87 caregivers of food allergic youth from a university-based allergy practice, $60 \%$ of caregivers reported that food allergy significantly affected meal preparation, and $49 \%$ indicated that food allergy affected family social activities.

In addition, $41 \%$ of parents reported more stress due to their child's allergy. ${ }^{38}$ In a similar study, 1,378 parents of 9-year-old children completed a questionnaire to gauge the effect of food allergy on their child's health-related quality of life. Youth with food allergy scored poorer on physical functioning, role/social limitations, general health, self-esteem, and family cohesion when compared with their non-allergic peers. ${ }^{39}$ Youth with food allergies are twice as likely to be bullied compared with peers without a medical condition. ${ }^{35}$ Older adolescents often begin to feel embarrassed by their food allergy and opt not to tell peers and others about their condition. Bullying and teasing can reinforce this maladaptive coping response as can older adolescents' poor decision making surrounding their personal health and poor communication with authority figures. ${ }^{40} \mathrm{It}$ is clear that food allergy burdens not only the patient with food allergy, both as a child and adolescent, but also family, peers, and other caregivers who are charged with monitoring and supporting the psychosocial well-being of the youth.

\section{DISEASE MANAGEMENT}

Successful food allergy management must consider not only the youth's dietary habits and needs but also their social and psychological needs. ${ }^{41}$ There is no cure for food allergy, and currently, the only treatment available for food allergy is avoidance of the offending food. ${ }^{11,42,43}$ Avoidance diets are complex and require vigilant adherence to reduce the risk of accidental exposure. ${ }^{44}$ Following diagnosis, all youth and their caregivers should be provided nutritional counseling ${ }^{10}$. A consultation with a dietitian should be considered when possible as a dietitian can provide in depth guidance and ensure that key nutrients are included in any avoidance diet. ${ }^{45-47}$ Health care professionals should be aware that the desire to "fit in," especially among older adolescents, may contribute to the difficulty in dietary management of food allergy by reducing the child's desire to adhere to an "abnormal" elimination diet. Furthermore, unintentional cross-contamination during food manufacturing, processing, and meal preparation does occur. This situation coupled with attending parties and social events during adolescence makes strict dietary avoidance of the offending

(C) Internet Journal of Allied Health Sciences and Practice, 2018 
food challenging. ${ }^{47}$

Severe or anaphylactic reactions require immediate epinephrine injection. In patients with a history of a severe food allergic reaction, epinephrine should be administered immediately even for mild, early onset symptoms, following ingestion of a known allergen. ${ }^{10,32}$ Commercially available brands of epinephrine auto-injectors include EpiPen, Adrenaclick, and AUVI-Q. If epinephrine is given, the youth must be taken immediately to the emergency department for further observation and treatment. ${ }^{48} \mathrm{As}$ a precautionary measure, youth with the potential for anaphylaxis should wear a medical identification bracelet that states their condition. All patients with a history of food-induced anaphylaxis or those with food allergy who are at significant risk for the development of anaphylaxis, such as food allergy combined with asthma or tree nut/peanut allergy, should always carry selfinjectable epinephrine. ${ }^{49}$ While the efficacy of additional pharmacotherapy for food-allergic reactions has not been well established, patients are frequently given antihistamines and corticosteroids. ${ }^{50}$ Nebulized bronchodilators are also administered when wheezing or asthma symptoms are present. ${ }^{50}$ Priobiotics are also emerging as a potential tool for food allergy management, although much more research is needed to establish their efficacy. ${ }^{51,52}$

While avoidance is the current treatment for food allergies, in clinical trials, new treatments for food allergy are being studied, including oral, sublingual, and epicutaneous immunotherapy. Oral immunotherapy consists of an initial dose escalation day 1 , followed by gradual dose buildup, then a prolonged maintenance phase with most patients receiving a significant level of desensitization. However, many patients do not achieve sustained responsiveness as when the food is withheld for a few weeks, the food allergy returns. Thus to remain "desensitized" to the food, it must be ingested on a regular, usually daily, basis. Representative studies include peanut, egg, and milk. Sublingual immunotherapy, studied mainly in peanut, has a very modest level of desensitization as the patient ingests a much smaller amount of food allergy protein than with oral immunotherapy and rarely achieves sustained unresponsiveness. However, sublingual immunotherapy carries much less risk of adverse events than oral immunotherapy. Studies with epicutaneous immunotherapy in which the food protein is placed on the skin in a "patch test" type approach, show a high degree of safety but achieve a much lower tolerated dose of the food allergen. Modified allergen immunotherapy approaches, such as peptide immunotherapy, are also being studied. Combining the above with medications, such as omalizumab, has also shown some improved safety outcomes. ${ }^{53}$ Furthermore, early dietary introduction of common allergenic foods, such as peanut, may prevent subsequent food allergy. The use of this approach with other foods has not been as successful to date. ${ }^{43,54}$

\section{APPLICABLE UNITED STATES FEDERAL LAWS}

In 2004, the United States (US) Congress took a positive step in addressing concerns surrounding food allergies by passing the Food Allergen Labeling and Consumer Protection Act. ${ }^{55}$ This law helps individuals with food allergies and those charged with their care avoid the health risks posed by the offending food allergens. This labeling law applies to all foods regulated by the US Food and Drug Administration (FDA) labeled after January 1, 2006. While more than 160 foods can cause allergic reactions, 8 common foods account for $90 \%$ of allergic reactions and are identified by this law (milk, eggs, fish, crustacean shellfish, tree nuts, peanuts, wheat, and soybeans). The labeling law stipulates that the name of the food source of a major food allergen must appear either in parentheses following the name of the ingredient (ie, lecithin [soy]), flour [wheat], whey [milk], etc.) or immediately after or next to the list of ingredients in a "contains" statement, such as "Contains wheat, milk, and soy". ${ }^{34}$ Flavoring, coloring, or incidental additives that bear or contain a major food allergen are also subject to the labeling requirements. ${ }^{55}$ The 2004 labeling law does not adequately address the additional 152 foods, such as banana, mango, pineapple, orange, celery, potato, and tomato, which cause the remaining $10 \%$ of allergic reactions.

Many manufacturers print food allergy information in bold letters on the label so that it stands out from the adjacent ingredient list. Some labels use the phrases "may contain... ", "produced on shared equipment with...", or "produced in a facility that also processes..." followed immediately by the common name of the major food allergen. The FDA requires nothing beyond labeling of items that explicitly contain the known food allergen. ${ }^{56,11}$ Use of ancillary phrases may be viewed as a prudent risk management strategy for food producing businesses. However, this vague labeling is a source of confusion for consumers and may result in the unnecessary exclusion of potentially safe food choices from the diets of people with allergies. ${ }^{11}$ Uncomplicated labeling standards are preferable.

While nearly all states allow students to carry their prescribed epinephrine auto-injector at school, many states have passed laws to allow schools to maintain emergency stocks of epinephrine. In 2013, the US Schools Access to Emergency Epinephrine Act was passed. This law incentivizes states to require that schools maintain and permit trained school personnel to administer epinephrine.$^{57}$ This law could potentially save the lives of thousands of children who are not aware they have a severe food allergy or are exposed to an allergen unintentionally. However, it should be noted that a potential barrier to epinephrine access is the soaring cost of the prescription. Since 2007, the price of an epinephrine autoinjector has increased over sixfold and may be

(C) Internet Journal of Allied Health Sciences and Practice, 2018 
unaffordable for some patient groups..$^{58}$ While pharmaceutical coupon programs and generics assist many patients by making these life-saving auto-injectors affordable, it is not the case for everyone, such as government-insured patients. Some manufacturers offer a prescription savings card that reimburses up to $\$ 300$ for out-of-pocket expenses to reduce the cost barrier to access. Sliding-fee scales are also offered by some manufacturers. Research is needed to determine the impact cost has on epinephrine access and utilization.

Another notable law affecting youth with food allergy is Section 504 of the Rehabilitation Act of 1973. This act is a US civil rights law that mandates equal treatment of youth with disabilities in federally funded public schools, private schools, and day care centers. Youth with severe, potentially life-threatening food allergies generally qualify under this provision. ${ }^{59}$ The rights of foodallergic youth are also protected by the Americans With Disabilities Act of 1990 (ADA). Title II of the ADA requires state or local government agencies that receive federal funds take necessary steps to ensure that no individual with a disability is treated differently than other individuals. Title III of the ADA requires organizations that do not receive federal funds (private day care centers, private schools, etc.) also take steps to ensure persons with a disability, such as food allergy, are treated in a nondiscriminatory manner. 60

Lastly, food-allergic adolescents have the right to privacy regarding their condition in addition to the right to be educated alongside their peers. Laws also exist to protect non-nursing professionals who give emergency care, such as epinephrine injections, to youth experiencing severe reactions. ${ }^{61}$ These Good Samaritan Laws exist in most states to protect individuals acting in good faith during emergencies. However, individuals who respond to emergencies, such as an anaphylactic reaction, should document the actions they do, see, and hear while providing care. This written account may serve as a legal document should litigation arise. ${ }^{62}$

\section{THE ROLE OF ALLIED HEALTH PROFESSIONALS}

Having legislation in place to protect food allergic youth is important. However, knowledge of and adherence to those laws is critical. At the broadest level, allied health professionals should understand and raise awareness among all the clients they serve about applicable food allergy laws and potential gaps in protection. For example, fewer than half of public schools in the United States employ a full-time school nurse, ${ }^{63}$ leaving other school personnel responsible for the management of students with severe allergies. As parents themselves, allied health professionals can advocate for appropriate nurse-to-student ratios in their school systems in order to avoid untrained staff responding to anaphylactic emergencies. In addition to advocacy, allied health professionals who work extensively with youth populations (athletic trainers, audiologists, dietitians) should be taught how to properly use epinephrine auto-injectors. This education could be embedded in college curricula or offered as on-the-job training to help prevent anaphylaxis-related fatalities.64,65 Human resource departments within allied health practices should also consider offering resuscitation training to all staff charged with caring for youth. ${ }^{41}$

Managing food allergies successfully requires a team effort because the majority of food allergy-related fatalities occur in settings away from the home ${ }^{49,66} \mathrm{~A}$ full $60 \%$ of children have their food-allergic reaction in schools or childcare facilities ${ }^{67}$ with as many as $25 \%$ of those reactions being first time reactions. ${ }^{68-70} \mathrm{~A}$ lack of formal written plans may cause personnel to feel uneasy about food allergy emergencies and may delay life-saving care. ${ }^{71,72}$ Health professionals interested in learning additional steps to take to accommodate food allergic children should review The School Food Allergy Program booklet produced by the Food Allergy \& Anaphylaxis Network (FAAN). ${ }^{59}$

One component of the booklet is the Food Allergy Action Plan, which describes steps to take in the event of an anaphylactic emergency. This plan is considered the gold standard and should be reviewed by allied health professionals to ensure that their agency's plan contains all of the FAAN components. ${ }^{72}$ Along with the youth's name and allergies, the plan also lists which treatment option is best for various symptoms, dosage information for medications, emergency contact phone numbers, and instructions about how to use an epinephrine auto-injector accompanied by a list of staff that have been trained to use them. ${ }^{59} \mathrm{In} 2013$, the Centers for Disease Control and Prevention (CDC) released "Voluntary Guidelines for Managing Food Allergies in Schools and Early Care and Education Programs," which is based in part on the FAAN model. ${ }^{73}$ Schools, health agencies, and allied health professionals who adopt written plans modeled after the FAAN and/or CDC recommendations take a crucial step toward helping food allergic youth successfully cope with this condition. 


\section{References}

1. Branum AM, Lukacs SL. Food allergy among U.S. children: trends in prevalence and hospitalizations. NCHS Data Brief. 2017;10:1-8. [PMID: 1991785]

2. Savage J, Johns CB. Food allergy: epidemiology and natural history. Immunol Allergy Clin North Am. 2015;35:45-9. [PMID: 25459576]

3. Hannaway PJ. On the Nature of Food Allergy. Marblehead: Lighthouse Press; 2007.

4. Leo HL, Clark NM. Managing children with food allergies in childcare and school. Curr Allergy Asthma Rep. 2007;7:187-91. [PMID: 17448329]

5. National Institute of Allergy and Infectious Diseases. Guidelines for the diagnosis and management of food allergy in the United States: report of the NIAID-sponsored expert panel. J Allergy Clin Immunol. 2010;126:S1-58. [PMID: 21134576]

6. Sicherer SH, Sampson HA. Food allergy. J. Allergy Clin Immunol. 2006;117:S470-5. [PMID: 16455349]

7. Jackson KD, Howie LD, Akinbami LJ. Trends in allergic conditions among children: United States, 1997-2011. NCHS Data Brief. 2013;121:1-8. [PMID: 23742874]

8. Liu T, Howard RM, Mancini AJ, Weston WL, Paller AS, et al. Kwashiokor in the United States: fad diets, perceived and true milk allergy and nutritional ignorance. Arch Dermatol Res. 2001;137:630-6. [PMID:11346341]

9. Noimark L, Cox HE. Nutritional problems related to food allergy in childhood. Pediatr Allergy Immunol. 2008;19:18895. [PMID: 18257908]

10. Boyce JA, Assa'ad A, Burks AW, Jones SM, Sampson HA, et al. Guidelines for the diagnosis and management of food allergy in the United States: report of the NIAID-sponsored expert panel. J Allergy Clin Immunol. 2011;126:S158. [PMID: 21310308]

11. Fiocchi A, Martelli A. Dietary management of food allergy. Pediatric Annals. 2006;35:755-63. [PMID:17048718]

12. Savage JH, Matsui EC, Skripak JM, Wood RA. The natural history of egg allergy. J Allergy Clin Immunol. 2007;120:1413-7. [PMID: 18073126]

13. Hasan SA, Wells RD, Davis CM. Egg hypersensitivity in review. Allergy Asthma Proc. 2013;1:26-32. [PMID: 23406934]

14. Shek LP, Soderstrom L, Ahlstedt S, Beyer K, Sampson HA. Determination of food specific lgE levels over time can predict the development of tolerance in cow's milk and hen's egg allergy. J Allergy Clin Immunol. 2004;114:387-91. [PMID: 15316521]

15. Spergel JM, Beausoleil JL, Pawlowsk NA. Resolution of childhood peanut allergy. Ann Allergy Asthma Immunol. 2000;85:473-6. [PMID: 11152168]

16. Zimmerman B, Urch B. Peanut allergy: children who lose the positive skin test response. J Allergy Clin Immunol. 2001;107:558-9. [PMID: 11240965]

17. Skolnick HS, Conover-Walker MK, Koerner CB, Sampson HA, Burks W, et al. The natural history of peanut allergy. J Allergy Clin Immunol. 2001;107:367-74. [PMID: 11174206]

18. Solensky R. Resolution of fish allergy: a case report. Ann Allergy Asthma Immunol. 2003;91:411-2. [PMID: 14582822]

19. Dharma C, Lefebvre DL, Tran MM, Lou WYW, Subbaarao, $P$, et al. Patterns of allergic sensitization and atopic dermatitis from 1 to 3 years: effects on allergic diseases. Clin Exp Allergy. 2017;Nov16:epub. [PMID: 29143385]

20. Lack G. Update on risk factors for food allergy. J Allergy Clin Immunol. 2012;129:1187-97. [PMID: 22464642]

21. Strachan DP. Hay fever, hygiene, and household size. BMD (Int Ed). 1989;299:1259-60. [PMID: 2513902]

22. Schafer T, Meyer T, Ring J, Wichmann HE, Heinrich J. Worm infestation and the negative association with eczema (atopic/nonatopic) and allergic sensitization. Allergy. 2005;60:1014-20. [PMID: 15969681]

23. Polosa R, Salvi S, DiMaria GU. Allergic susceptibility associated with diesel exhaust particle exposure: clear as mud. Arch Environ Health. 2002;57:188-93. [PMID: 12507171]

24. Black MH, Zhou H, Takayanagi M, Jacobsen SJ, Koebnick C. Increased asthma risk and asthma-related health care complications associated with childhood obesity. Am J Epidemiol. 2013;178:1120-8. [PMID:23924576]

25. Eggesbo M, Botten G, Stigum H, Nafstad P, Magnus P. Is Delivery by Cesarean Section a Risk Factor for Food Allergy? J Allergy Clin Immunol. 2003;112:420-6. [PMID: 12897751]

26. Skypala I, Vlieg-Boerstra B. Food intolerance and allergy: increased incidence or contemporary inadequate diets? Curr Opin Clin Nutr Metab Care. 2014;7:442-7. [PMID: 25003529]

27. Ekmay RD, Coon CN, Ladics GS, Herman RA. Allergenic potential of novel proteins - what can we learn from animal production? Regul Toxicol Pharmacol. 2017;89:240-3. [PMID: 28751264] 
28. Green TD, LaBelle VS, Steele PH, Kim EH, Lee LA, et al. Clinical characteristics of peanut-allergic children: recent changes. Pediatrics. 2007;120:1304-10. [PMID: 18055680]

29. Smith PK. The false alarm hypothesis: food allergy is associated with high dietary advanced glycation end-products and proglycating dietary sugars that mimic alarmins. J Allergy Clin Immunol. 2017;139:429-37. [PMID: 27544741]

30. Sicherer SH, Munoz-Furlong A, Murphy R, Wood RA, Sampson HA. Symposium: Pediatric food allergy. Pediatrics. 2003;111:1591-4. [PMID: 12777597]

31. Food Allergy \& Anaphylaxis Network. Diagnosis \& Testing [Internet]. 2017. Available from: https://www.foodallergy.org/life-with-food-allergies/food-allergy-101/diagnosis-testing. Accessed October 1 , 2017.

32. Sampson HA, Aceves S, Bock SA, James J, Jones S, et al. Food allergy: a practice parameter update-2014. J Allergy Clin Immunol. 2014;134(5):1016-25,e43. [PMID: 25174862]

33. Bernstein L, Li J, Bernstein D, Hamilton R, Spector S, et al. Allergy diagnostic testing: an updated practice parameter. Ann Allergy. 2008;100(3):S1-48. [PMID: 18431959]

34. United States Food and Drug Administration. Food Facts from the U.S. Food and Drug Administration: Food Allergies - What You Need to Know [Internet]. 2017. Available from: https://www.fda.gov/downloads/Food/ResourcesForYou/Consumers/UCM220117.pdf. Accessed October 31, 2017.

35. Food Allergy Research \& Education. Facts and Statistics [Internet]. 2017. Available from: https://www.foodallergy.org/life-food-allergies/food-allergy-101/facts-and-statistics. Accessed October 31, 2017.

36. Fox AT, Du TG, Lang A, Lack G. Food allergy as a risk factor for nutritional rickets. Pediatr Allergy Immunol. 2004;15:566-9. [PMID: 15610373]

37. Sampson HA. The evaluation and management of food allergy in atopic dermatitis. Clin Dermatol. 2003;21:183-92. [PMID: 12781436]

38. Bollinger ME, Dahlquist LM, Mudd K, Sonntag C, Dillinger $L$, et al. The impact of food allergy on the daily activities of children and their families. Ann Allergy Asthma Immunol. 2006;96:415-21. [PMID: 16597075]

39. Ostblom E, Egmar AC, Gardulf A, Lilja G, Wickman M. The impact of food hypersensitivity reported in 9-year-old children by their parents on health-related quality of life. Allergy. 2008;63:211-8. [PMID:18186811]

40. Sampson HA, Munoz-Furlong A, Sicherer SH. Risk-taking and coping strategies of adolescents and young adults with food allergy. J Allergy Clin Immunol. 2006;117:1440-5. [PMID: 16751011]

41. Hodges B, Clack G, Hodges I. Severe allergy: an audit and service review. Pediatr Nurs. 2006;19:26-31. [PMID: 18047169]

42. Ewan PW, Clark AT. Efficacy of a management plan based on severity assessment in longitudinal and casecontrolled studies of 747 children with nut allergy: proposal for good practice. Clin Exp Allergy. 2005;35:751-6. [PMID: 15969666]

43. Dutoit G, Foong RM, Lack G. Prevention of food allergy: early diet interventions. Allerg Int. 2016; 65:370-7. [PMID: 27617655]

44. Wood RA. The natural history of food allergy. Pediatrics. 2003;111:1631-7. [PMID: 12777603]

45. Rosenthal M. How a non-allergist survives an allergy clinic. Arch Dis Child. 2004;89:238-43. [PMID: 14977702]

46. McKevith B, Theobald H. Common food allergies. Nurs Stand. 2005;19:39-42. [PMID: 15819332]

47. Noimark L, Cox HE. Nutritional problems related to food allergy in childhood. Pediatr Allergy Immunol. 2008;9:18895. [PMID: 18257908]

48. Lee JM, Greenes DS. Biphasic anaphylactic reactions in pediatrics. Pediatrics. 2000;106:762-6. [PMID: 11015520]Pumphrey RS. Lessons for management of anaphylaxis from a study of fatal reactions. Clin Exp Allergy. 2000;30: 1144-50. [PMID: 10931122]

49. Muraro A, Roberts G, Clark A, Eigenmann PA, Halken S, et al. The management of anaphylaxis in childhood: position paper of the European Academy of Allergology and Clinical Immunology. Allergy. 2007;62:857-71. [PMID: 17590200]

50. Castellazzi AM, Valsecchi C, Caimmi S, Licari A, Marseglia A, et al. Probiotics and food allergy. Ital J Pediatr. 2013;39:47. [PMID: 23895430]

51. Del Giudice MM, Rocco A, Capristo C. Priobiotics in the atopic march: highlights and new insights. Dig Liver Dis.2006;38:S288-90. [PMID: 17259093]

52. Wood RA. Food allergen immunotherapy: current status and prospects for the future. J Allergy Clin Immunol. 2016;137:973-82. [PMID: 27059725]

53. Perkin MR, Logan K, Tseng A, Raji B, Ayis S, et al. Randomized trial of introduction of allergenic foods in breastfed infants. N Engl J Med. 2016;374:1733-43. [PMID: 26943128] 
54. United States Food and Drug Administration. Food Allergen Labeling and Consumer Protection Act of 2004 (Title II of Public Law 108-282) [Internet]. 2004. Available from: https://www.fda.gov/downloads/Food/GuidanceRegulation/UCM179394.pdf. Accessed October 15, 2017.

55. United States Food and Drug Administration. Questions and Answers Regarding Food Allergens, Including the Food Allergen Labeling and Consumer Protection Act of 2004, Fourth Edition [Internet]. 2006. Available from: https://www.fda.gov/downloads/Food/GuidanceRegulation/UCM301394.pdf. Accessed October 31, 2017.

56. School Access to Emergency Epinephrine Act of 2013, Pub. L. No. 113-48, 127 Stat. 575 and 576 (November 13, 2013).

57. Chua K, Conti RM. Out-of-pocket spending among commercially insured patients for epinephrine autoinjectors between 2007 and 2014. J Am Med Assoc. 2017;177:736-9. [PMID: 28346591]

58. Food Allergy \& Anaphylaxis Network. The School Food Allergy Program. Fairfax; The food allergy \& anaphylaxis network: 2005.

59. Americans With Disabilities Act of 1990, Pub. L. No. 110-325, 104 Stat. 327 (July 26, 1990).

60. Gaudreau JM. The challenge of making the school environment safe for children with food allergies. J Sch Nurs. 2000;16:5-10. [PMID: 11151543]

61. American Red Cross. Emergency Response. Yardley; Staywell: 2001.

62. Robert Wood Johnson Foundation. School Nurse Shortage May Imperil Some Children, RWJF Scholars Warn [Internet]. 2013. Available from: http://www.rwjf.org/en/library/articles-and-news/2013/12/School-Nurse-ShortageMay- Imperil-Some-Children.html. Accessed October 1, 2017.

63. Gold MS, Sainsbury R. First aid management in children who were prescribed an epinephrine autoinjector device (EpiPen). J Allergy Clin Immunol. 2000;106:171-6. [PMID: 10887321]

64. Rhim GS, McMorris MS. School readiness for children with food allergies. Ann Allergy Asthma Immunol. 2001;86:172-6. [PMID: 11258686]

65. Munoz-Furlong A. Food allergy in schools: concerns for allergists, pediatricians, parents, and school staff. Ann Allergy Asthma Immunol. 2004;93:S47-50. [PMID: 15562874]

66. Yu JW, Kagan R, Verreault N, Nicolas N, Joseph L, et al. Accidental ingestions in children with peanut allergy. Ann Allergy Asthma Immunol. 2006;18:466-72. [PMID: 16890773]

67. Sicherer SA, Furlong TJ, DeSimone J, Sampson HA. The U.S. peanut and tree nut allergy registry: characteristics of reactions in schools and day care. J Pediatr. 2001;138:560-5. [PMID: 11295721]

68. McIntre CL, Sheetz AH, Carroll CR, Young MC. Administration of epinephrine for life-threatening allergic reactions in school settings. J Pediatr. 2005;116:1134-40. [PMID: 16264000]

69. Wegrzyn AN, Conover-Walker MK, Wood RA. Food-allergic reactions in schools and preschools. Arch Pediatr Adolesc Med. 2001;155:790-5. [PMID: 11434845]

70. Hay GH, Harper TB, Moore TG. Assuring the safety of severely food allergic children in school. J Sch Health. 2006;76:479-81. [PMID: 17026642]

71. Powers J, Bergren MD, Finnegan L. Comparison of school food allergy emergency plans to the food allergy and anaphylaxis network's standard plan. J Sch Nurs. 2007;23:252-8. [PMID: 17894522]

72. Centers for Disease Control and Prevention. Voluntary Guidelines for Managing Food Allergies in Schools and Early Care and Education Programs [Internet]. 2013. Available from:

http://prod.fare.beaconfire.us/sites/default/files/2017-09/cdc-guidelines.pdf. Accessed November 7, 2017. 